\title{
外乱に対して安定な学習機能をもつ ファジィコントローラ
}

\author{
丹治 順一*。下光 夫*
}

\section{A Fuzzy Controller with a Robust Learning Function}

\author{
Jun-ichi TanjI* and Mitsuo Kinoshita*
}

A self-organizing fuzzy controller is able to use linguistic decision rules of control strategy and has a strong adaptive property by virture of its rule learning function. While a simple linguistic description of the learning algorithm first introduced by Procyk, et al. has much flexibility for applications to a wide range of different processes, its detailed formulation, in particular with control stability and learning process convergence, is not clear.

In this paper, we describe the formulation of an analytical basis for a self-organizing fuzzy controller by using a method of model reference adaptive control systems (MRACS) for which stability in the adaptive loop is theoretically proven. A detailed formulation is described regarding performance evaluation and rule modification in the rule learning process of the controller. Furthermore, an improved learning algorithm using adaptive rule is proposed. An adaptive rule gives a modification coefficient for a rule change estimating the effect of disturbance occurrence in performance evaluation. The effect of introducing an adaptive rule to improve the learning convergency is described by using a simple iterative formulation.

Simulation tests are presented for an application of the proposed self-organizing fuzzy controller to the pressure control system in a Boiling Water Reactor (BWR) plant. Results with the tests confirm the improved learning algorithm has strong convergent properties, even in a very disturbed environment.

* (株) 日立製作所エネルギー研究所 日立市森山町 1168

* Energy Research Laboratory, Hitachi, Ltd., Hitachi (Received October 28, 1986)

(Revised July 21, 1987)
Key Words: fuzzy control, self-organizing, adaptive control, plant control

\section{1.はじめに}

近年，ディジタル制御をプラント制御に導入し，制 御性能を高度化する試みが盛んである. なかであ，運 転員の有する制御知識を直接活用できるファジィ制御 は，運転制御を自動化する場 合に有効な制御方式と して, 各種動的システムへの応用が試みられてい

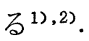

ファジィ制御は，あいまい命題の形式で表現された 一群の制御ルールに基づきファジィ推論によって制御 動作を決定するもので，Mamdani らの応用研究以 来 ${ }^{3)}$, 制御ルールの学習機能を付加するなど制御性能 向上のための努力がなされている(4).5). 制御ルールの 学習機能は, モデルと実プラントの特性差や運転条件 変化に伴うプラント特性の変化に適応してルールの修 正を行わせるもので, 高度な制御性能が要求されるプ ラントへの応用が注目されている.

しかしながら，学習機能付ファジィコントローラを 実機に応用するにあたって，試行錯誤によらない制御 系の詳細な設計を可能とするためには，学習のアルゴ リズムを明確に定式化するととが重要である。すなわ ち, 制御性能の評価方法, 学習サンプリング周期とル ール修正量の関係などを明らかにする必要がある。

そこで本論文ではまず，モデル規範形適応制御系の 設計方法 ${ }^{6)}$ を基に，制御偏差を制御出力修正量の決定 に用いる形式の適応制御系を構成し，乙の適応制御系 から学習機能付ファジィコントローラの基本制御モデ ルを導く. この基本制御モデルを用いて，学習アルゴ リズムを定式化する，つぎに，耐外乱性を高めるため に，外乱の影響を推定してルール修正量を調整するよ うな改良学習アルゴリズムを提案し，簡単な数式モデ 
ルを用いてその有効性を示す.

さらに本論文では，プラントへの応用例として，沸 騰水形 (BWR) 発電プラントの圧力制御系に, 提案し た学習機能付ファジィコントローラを適用した場合の シミュレーション結果を示し，その有効性を検討す る.

\section{2. 学習機能付ファジィコントローラ}

本章では，まずモデル規範形の適応制御系の数式モ デルを基に学習機能付ファジィコントローラの基本構 成を決定し，学習アルゴリズム定式化の基礎となる制 御モデルを導く.つぎに, 学習機能付ファジィコント ローラの演算動作とその基礎式を示す.

\section{1 基本構成}

以下，モデル規範形適応制御系の基礎理論 ${ }^{6), 7)}$ と同 様の考え方に従って, Fig. 1 に示すような適応制御 系のモデルを検討する. 通常，モデル規範形の適応制 御系では適応コントローラの入力としてプラントと規 範モデルの出力誤差を用いるが（出力を破線で示す）, ここでは学習機能付ファジィコントローラの基本構成 を導くために，制御偏差を適応コントローラの入力と する (出力を実線で示す) 形式の適応制御系を考える.

プラントおよび規範モデルは，以下に示すように， ファジィコントローラの設計に用いるプラント動特性 の定性的モデルとの対応付けが容易な，1次遅れ伝達 関数のモデルとする.

$$
\begin{aligned}
& \text { プラント : } \\
& \dot{x}(t)=-a x(t)+b u(t)
\end{aligned}
$$

規範モデル :

$$
\dot{x}_{m}(t)=-a_{m} x_{m}(t)+b_{m} u_{m}(t)
$$

ただし， $a, b$ は未知, $a_{m}, b_{m}$ は既知の定数で, $a, a_{m}>$ $0, b, b_{m} \neq 0$ である. ここで, 出力鿁差を $\varepsilon_{x}(t)=x_{m}(t)$ 一 $x(t)$ と执，(1)，(2)式の差をとると, つぎの誤 差方程式が求まる.

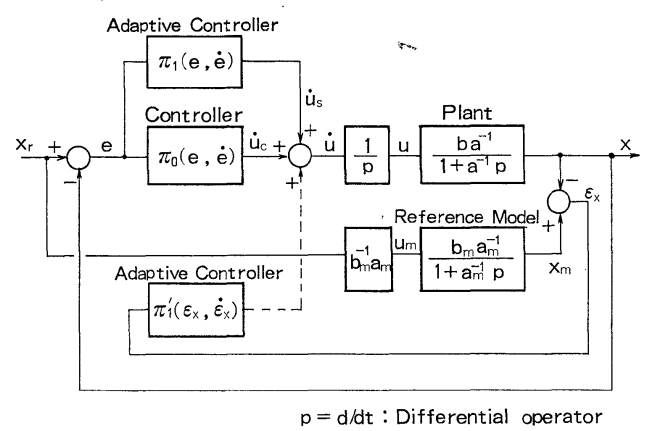

Fig. 1 A simplified block diagram of the model reference adaptive control system (MRACS)

$$
\dot{\varepsilon}_{x}(t)+a_{m} \varepsilon_{x}(t)=-\left(a_{m}-a\right) x(t)+b_{m} u_{m}(t)-b u(t)
$$

出力誤差, およびその变化率の収束 $\left(\varepsilon_{x}(t) \rightarrow 0, \dot{\varepsilon}_{x}(t) \rightarrow\right.$ $0 ）$ が保証されるような制御出力 $u(t)$ の変化を，リア プノフの方法により求めると以下のようになる.

$$
\begin{aligned}
\dot{u}(t)= & \hat{b}^{-1} \hat{a} \cdot \Delta t^{-1} \cdot a_{m} \int\left\{\left(2 \hat{a} \cdot a_{m}^{-1}-1\right) \hat{a}^{-1} \dot{e}(t)+e(t)\right\} d t \\
& +\zeta_{1} \hat{b}^{-1} a_{m}^{2}\left(a_{m}^{-1} \dot{e}(t)+e(t)\right)
\end{aligned}
$$

ここで, $\hat{a}, \hat{b}$ はプラントの未知パラメータの推定值, $e(t)=x_{r}(t)-x(t)$ は制御偏差, $\Delta t$ はサンプル.周期, $x_{r}(t)$ は制御変数の目標值, $\zeta_{1}$ はコントローラの出力 を調整するためのパラメータである. (4)式の導出で は，規範モデルへの制御入力と目標值の関係， $a_{m} x_{r}$ $(t)-b_{m} u_{m}(t)=0$, および $\dot{\varepsilon}_{x}(t)+a_{m} \varepsilon_{x}(t)=\dot{e}(t)+a_{m} e(t)$ 一 $\dot{x}_{r}(t)$, の関係式を用いた. (4) 式の右辺第 1 項 は，プラントと規範モデルのパラメータ差を補償する 項である. 第 2 項は, 目標值変更に対応したコントロ 一ラ出力 $\left(\dot{u}_{c}(t)\right)$ である. 調整パラメータ $\zeta_{1}$ の值は, $\zeta_{1}>1-\hat{a} a_{m}^{-1}$ であればリアプノフの方法により出力 誤差の零への収束が保証されて, 制御安定性を確保し つつ適応動作を実現できる（4)式は，右辺第 1 項を 加算形式で表わすと, 次式のようになる.

$$
\dot{u}\left(t_{n}\right)=M^{-1}\left(\frac{1}{T_{m}}\right) \sum_{i=1}^{n} P\left(t_{i}\right)+\dot{u}_{c}\left(t_{n}\right)
$$

ことで, $\int_{t_{n-1}}^{t_{n}} d t=\Delta t, T_{m}=a_{m}^{-1}$ であり, $M=\hat{b} \hat{a}^{-1}$ は プラントのモデルゲインの推定值である. $P\left(t_{i}\right)$ はプラ ントの応答が規範モデルのような所望の応答を示して いるかどうか，制御性能を評価する関数とみなせるあ ので, 次式のように偏差とその変化率の線形和となる.

$$
P\left(t_{i}\right)=e\left(t_{i}\right)+T_{c} \dot{e}\left(t_{i}\right)
$$

ただし， $T_{c} \equiv\left(2 \hat{a} a_{m}^{-1}-1\right) \hat{a}^{-1}$ はプラントの修正時定数 である. 制御偏差を適応コントローラの入力として用 いる適応制御系のブロック図を Fig. 2 亿示す.

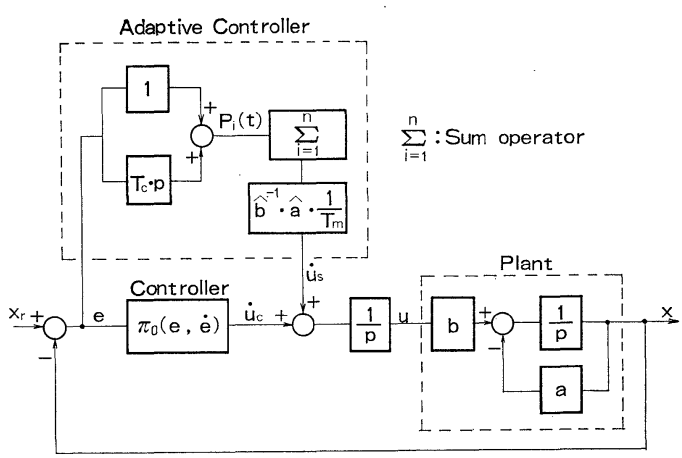

Fig. 2 A block diagram of the fundamental control model for a self-organizing fuzzy controller 
ここで，(5)式の右辺第 1 項の加算項によるコント ローラ出力の補正は, コントローラ出力 $\left(\dot{u}_{c}(t)\right)$ を与 える関数 $\pi_{0}(e, \dot{e})$ を逐次補正する方法であ害現できる ので, Fig. 2 は学習機能付ファジィコントローラの基 本制御モデルを示すものと考えられる.

また，(1) 式と(6) 式から $P\left(t_{n}\right) \simeq x_{r}\left(t_{n}\right)-C \cdot u_{c}\left(t_{n}\right)$ (ただし, $\left.C \equiv b a^{-1}, \dot{x}_{r}\left(t_{n}\right) \simeq 0\right)$ となるので, これと(5) 式 の逐次形式による表現を考慮すると次式が得られる.

$$
P\left(t_{n}\right)-P\left(t_{n-m}\right)=-C M^{-1} P\left(t_{n-m}\right)
$$

ただし， $m$ は規範モデルの時定数に等価なサンプリン グ数 $\left(T_{m}=m \Delta t\right)$ であり, 適応動作時の収束を完了す るために必要な時間の目標值である。（7 式は，学習 機能付ファジィコントローラの, 性能評価值フィード バックによる学習の近似的な関係式であり，後述する 改良学習アルゴリズムの検討において用いる.

\section{2 演算動作の概要}

前節で導出した学習動作の基本式（( 5 )式）を基之 して構成した，学習機能付ファジィコントローラのブ ロック図を Fig. 3 に示す．本ブロック図は，アルゴ リズム改良のために付加した破線部分を除いて，先に Procyk らによって与えられた学習機能付ファジィコ ントローラの基本ブロック図 ${ }^{4)}$ と同一の構成をとる。

以下，演算動作の概要と，制御モデルから導かれるそ の基礎式を示す.

つぎのようなあいまい制御ルールを考える.

$\operatorname{IF}\left[\left\{E\right.\right.$ is $\left.F_{i}\right\}$ AND $\left\{C E\right.$ is $\left.\left.G_{i}\right\}\right] \operatorname{THEN}\left[\Delta U\right.$ is $\left.H_{i}\right]$ $e \in E, c e \in C E, \Delta u \in \Delta U, i=1, \cdots k$

こてで, 大文字 $E, C E$ は制御偏差とその変化率に対 するファジィ変数， $\Delta U$ は制御出力の変化分を表わす ファジィ変数, $F_{i}, G_{i}, H_{i}$ はそれぞれの変数がとる 值，小文字 $e, c e, \Delta u$ は離散集合 $\{-6,-5, \cdots 0, \cdots 6\}$ 上で定義されている量子化变数である。 あいまい制御 ルールの具体例として，シミュレーションで用いたル ールテーブルの例を Fig. 4 亿示す. なお，ファジィ 変数己量子化変数を対応づけるメンバーシップ関数 は，通常多く使用されているものを用いた5゙.

ファジィ制御では，上記のようなあいまい制御ルー

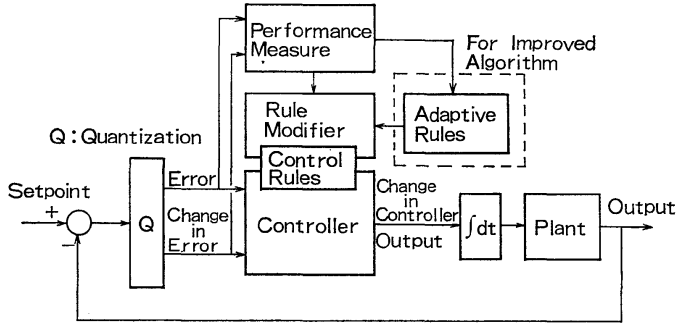

Fig. 3 Block diagram of the self-organizing fuzzy controller

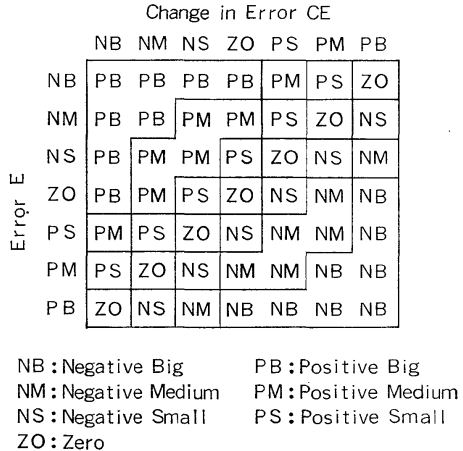

Fig. 4 Rule table to select the change in controller output

ルから, 制御偏差 $e$ とその変化率 $c e$ を入力としたと き, 出力である制御出力変化分をファジィ推論により 決定する. 推論法しては種々の方法があるが，乙こで は推論合成則を用いる直接法の一つである, Mamdani による $\min$ オペレーションに従って, $k$ 個のルール による総合推論結果 $H^{0}$ を次式で求める ${ }^{8)}$.

$$
H^{0}=\max _{i}\left\{F_{i}(e) \wedge G_{i}(c e) \wedge H_{i}(\Delta u)\right\}
$$

制御出力変化分 $\Delta u^{0}$ は, $H^{0}$ を確定值へ解釈変換し て求める. その方法としては，ファジィ出力の重心を とる方法 ${ }^{5)}$ な゙，いくつかの提案があるが，ててでは 計算が簡単な, 最大のメンバーシップ值を与える $\Delta u_{i}$ の平均值をとる方法を採用した，実際には，記憶エリ アと計算時間の短縮のために前もってすべての制御状 態 $(e, c e)$ に対して制御出力の変化分 $\Delta u$ を計算で求 めて拉，参照テーブル化して用いた。

ファジィ制御におけるルールの学習機能は，まず制 御偏差とその変化率から制御状態の目標からのずれを 評価して性能評価值を求める.つぎにての性能評価值 に比例した制御出力変化分の修正量を求め，乙れを用 いて制御出力の変化分を与える参照テーブルを修正す る. 性能評価值を与える関数 $\pi_{1}\left(e_{n}, c e_{n}\right)$ の基礎式は, (6)式を無次元化し，かつ離散的な值をとるように量 子化して得られる.

$$
p_{n}=\frac{e\left(t_{n}\right)}{\Delta e^{*}}+\left(\frac{T_{c}}{l \Delta t}\right) \frac{\dot{e}\left(t_{n}\right)}{\Delta \dot{e}^{*}}
$$

ここで, $p_{n}$ はサンプリング時期 $t_{n}$ の性能評価值, $\Delta e^{*}$ は量子化のための単位偏差, $\Delta e^{*}$ は偏差の変化率 を量子化するための単位変化率を示し, $\Delta \dot{e}^{*}=\Delta e^{*} / l \Delta t$ とする.ただし， $l$ は定数， $\Delta t$ はサンプル周期であ る. 量子化した偏差変化率の係数 $\left(T_{c} / l \Delta t\right)$ は, 通常 サンプル周期を時定数に依存させて決めるので, プラ ントの時定数によらない一定值とすることができる.

制御ルールの修正部では, 性能評価值をとり込んで 
制御出力の変化分を修正する量を求め,つぎに示すよ うに制御ルールを修正する4).

$\operatorname{IF}\left[\left\{E\right.\right.$ is $\left.\mathscr{F}\left(e_{n-m}\right)\right\}$ AND $\left\{C E\right.$ is $\left.\left.\mathscr{I}\left(c e_{n-m}\right)\right\}\right]$

THEN $\left[\Delta U\right.$ is $\left.\mathscr{F}\left(\Delta u_{n-m}+\Delta r_{n}\right)\right]$

こてで, 古は実変数をファジィ変数に変換する関数, $\Delta r_{n}$ は制御出力の変化分を修正する量である.すなわ $ち$, 現時点（サンプリング時期 $t_{n}$ ）よりプラントの応 答遅れ時間 $m \Delta t(m$ サンプリング) だけ以前に使用 されたルールが現在の制御性能に影響を与えていると 考え，そのルールを修正する. 修正量 $\Delta r_{n}$ は, 前節 で述べた制御モデルでは (5) 式の右辺第 1 項の逐次加 算分㑑相するもので，量子化の式を考慮すると，無 次元化したモデルゲイン $M^{*}$ を用いて次式で求める.

$$
\Delta r_{n}=M^{*-1} \cdot p_{n}
$$

ここで, $M^{*-1}=\left(\Delta e^{*} / \Delta u^{*}\right)\left(\Delta t / T_{m}\right) M^{-1}, \Delta u^{*}$ は制御 出力の変化を量子化する定数である.

\section{3. 学習アルゴリズムの拡張}

本章では，改良学習アルゴリズムとして，(1)制御 ルールの学習における外乱の影響を小さくするよう な，適応ルールを用いたルール修正方式と，(2) 学習 での修正対象とするルールとして, 使用条件が隣接す るルール群を選択するような，ルール修正方式につい て述べる.

\section{1 適応ルールを用いたルール修正}

制御の性能評価值は，使用した制御ルールが目標と する応答を実現しているから゙うかを評価するために用 いるあのであるが，外乱の影響を少なくするためには ある時間幅に渡る応答を評価すべきと考える，そと で, Fig. 3 亿破線で囲んだ適応ルール記憶部に, 現時 点および過去の性能評価值 $P_{n}, P_{n-m}$ の值をみてルー ル修正の修正係数 $\xi_{n}$ を与える適応ルールを用意して おき，(10)式に替えて次式で参照テーブルの值の修正 分を決定する ${ }^{9}$.

$$
\Delta r_{n}=\xi_{n} \cdot M^{*-1} \cdot p_{n}
$$

適応ルールを用いたルール修正アルゴリズムのフロー チャートを Fig. 5 亿示す. 適応ルールは, 性能評価 值の変動傾向加ら外乱有と推定される場合に，学習に おける外乱の影響を小さくするように，修正係数 $\xi_{n}$ を与える，適応ルールはつぎのように表現できる.

$\operatorname{IF}\left[\left\{P_{0}\right.\right.$ is $\left.Q_{i}\right\}$ AND $\left\{P_{-}\right.$is $\left.\left.S_{i}\right\}\right]$ THEN $\left[\xi\right.$ is $\left.T_{i}\right]$ ここで， $P_{0}, P_{-}$はそれぞれ現時点およびプラントの応 答遅れだけ過去の性能評価值を表わすファジィ变数, $\xi$ は修正係数を表わすファジィ変数， $Q_{i}, S_{i}, T_{i}$ はそ れぞれの変数がとる值である. 適応ルールの基礎とな るべきモデル式を以下に述べる.

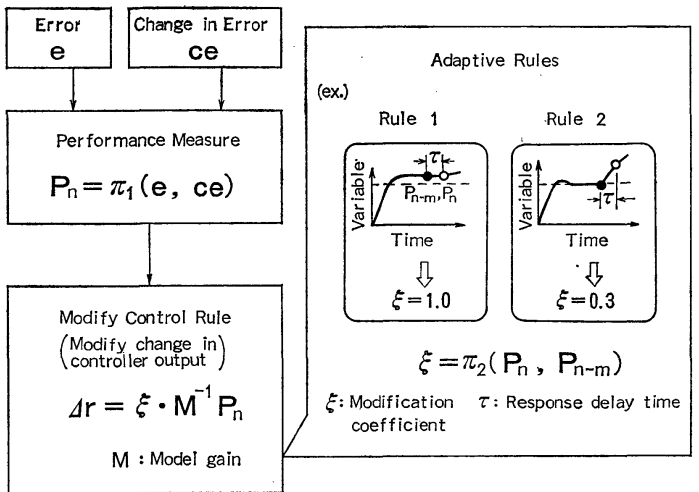

Fig. 5 Flowchart of control rule modification in the rule learning process

制御ルールを学習させた場合の性能評価値の変化を 表わす $(7)$ 式において, $C M^{-1}=C(t)(C(t) \simeq 1.0)$ とお き, 外乱による性能評価值の变化分 $\delta P_{v}$ を考慮する 之次式が得られる.

$$
p_{n}-p_{n-m} \simeq-C(t) p_{n-m}+\delta p_{v}
$$

すなわち，プラントのモデルゲインが適切に与えられ $(C(t) \simeq 1)$, かつ外乱がなければ $\left(\delta p_{v} \simeq 0\right)$, 学習を繰返 すととにより目標の制御性能 $\left(P_{n} \simeq 0\right)$ が達成できる. ここで修正係数を, 性能評価值の, 外乱がないとした 場合の推定值と実際の值との比とおくと，つぎのよう になる。

$$
\xi_{n} \equiv \frac{\hat{p}_{n}}{p_{n}}=\frac{p_{n}-\delta p_{v}}{p_{n}}=(1-C(t)) \frac{p_{n-m}}{p_{n}}
$$

学習による制御ルールの修正において, 最適な值か ら 100\% を超過するような極端に誤差の大きい修正量 が与えられるととはないと仮定し $(0 \leq C(t) \leq 2)$, 更に, 性能評価値の正負符号の逆転 $\left(P_{n-m} / P_{n}<0\right)$ と修正ゲ インの超過 $(C(t)>1)$ が対応するとみなすと, (13) 式 から次式が成立する.

$$
0 \leq \xi_{n} \leq\left|p_{n-m}\right| P_{n} \mid
$$

適応ルールを作成するにあたっては，(14)式を基礎 式として使用するが，実際にはプラントの非線形特性 之応答遅れ時間のあいまいさを考慮して修正ゲインの 適当な誤差を仮定し（たとえば $|1-C(t)|=0.5)$, 修 正係数の最大值は安全側に $\xi_{n}=1.0$ とおいて, ファジ ィ変数で表現する. Fig. 6 にシミュレーションで用 いた適応ルールのテーブルを示す．乙のような適応ル ールを用いた場合のシミュレーション結果は 4 章で述 べる.

つぎに，修正すべき制御ルールの選定方法を Fig. 7 を用いて述べる. 制御変数の目標值をステップ的に変 更したときのプラントの応答を, 偏差とその変化率を 縦軸と横軸とするルール平面上の軌跡で表わすと, 図 


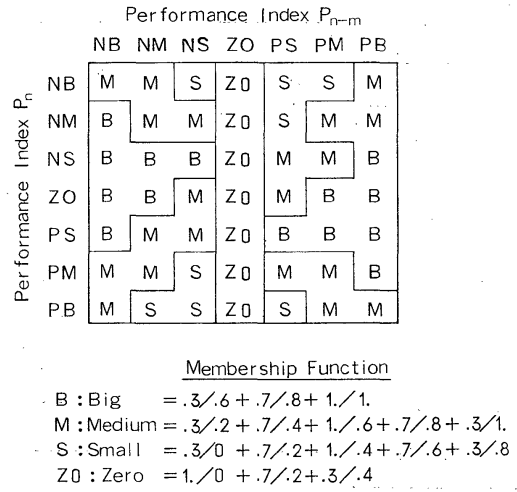

Fig. 6 Adaptive rule table to select the modification coefficient

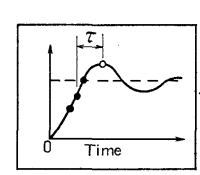

(a). Step response

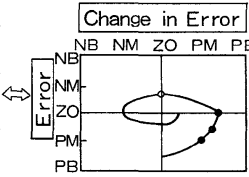

(b) Response locus on rule plane

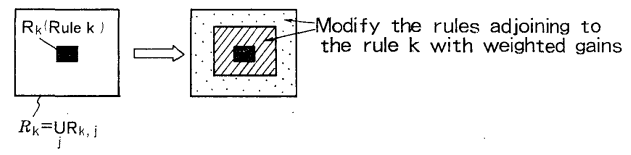

Modification of
the clustered rules $\left\{\begin{array}{l}\bullet \text { Considering fuzziness of } \\ \text { response delay time } \tau \\ \cdot \begin{array}{l}\text { Keeping continuity of } \\ \text { rules }\end{array}\end{array}\right.$

Fig. 7 Method to select the rules to be modified

の ( b ) に示すように原点に向う渦巻状の曲線となる. ここで白丸印で示す時点の制御状態に影響を与えた制 御ルールは，その時点よりあプラントの応答遅れ時間 てだけ過去に使用された制御ルール（黒丸印で示す） であると考えられる. しかし，乙の応答遅れ時間はあ る幅をもったあいまいな量であり，正確な值を特定す るととは困難である，また，偏差とその変化率の座標 面で使用すべきルールは決っているので, 使用条件 が互いに隣接するルールは類似の制御状態下で使用さ れる. そこで，従来は罒の左下部に示すように，実際 に使用された制御ルール $R_{k}$ のみを修正対象のルール としていたが，改良学習アルゴリズムでは図の右下に 示すように，応答遅れ時間から決まる制御ルール $R_{k, 0}$ に使用条件が隣接するルール群 $\mathcal{R}_{k}=\bigcup_{j} R_{k, j}$ の参照テ ーブルの設定值を，重み付きで群修正するとととし た.

$$
\Delta u_{k, j}=\Delta u_{k, j}+g(j) \cdot \Delta r_{n} \quad(j=1, \cdots \lambda)
$$

ここで, $\Delta u_{k, j}$ は制御ルール $R_{k, 0}$ に隣接するルール 群 $\mathscr{R}_{k}$ の $j$ 番目の制御ルールに対する制御出力変化 分の設定值, $g(j)$ は, ルール平面の制御ルール $R_{k, 0}$
を定める偏差とその変化率にそれぞれ対応するメンバ ーシップ関数を求め, それらの積から決める.

\section{2 学習収束性の検討}

学習により制御ルールを修正する場合に，最適な制 御ルールにいつまです収束しない，または逆に発散し て不安定な挙動を示すととがあるが，その原因として 以下のととが挙げられる.

（1）外乱の影響を受けた性能評価值をそのままル ール修正に用いている.

（2）モデルゲイン $M$ の設定值が不適当である.

（3）プラント応答遅れ時間の推定值が誤ってい る.

ここでは，3.1 節で述べた改良学習アルゴリズムの， 上記の問題に対する効果について検討する.

適応ルールを用いない従来の学習アルゴリズムによ り制御ルール $R_{k}$ を修正する場合, 現時点より $m$ サ ンプリング後に再度制御ルール $R_{k}$ が使用されたとき の新たな性能評価值は, (7) 式と (12) 式を考慮して次 式で求められる.

$$
\begin{aligned}
P_{i+1} & =\hat{P}_{i}-\Delta P_{i}+\delta P_{v i+1} \\
& =\left(1-C M^{-1}\right) P_{i}-\delta P_{v i}+\delta P_{v i+1}
\end{aligned}
$$

ここで, $\Delta P_{i}=C M^{-1} P_{i}$ はルール修正による性能評価 值の変化分, $\hat{P}_{i}$ は外乱を含まない真の性能評価值を 示す. いま学習の収束に対して最も箃しい条件とし て，外乱がルール修正の周期で変動している場合，す なわち, $\delta P_{v i}=(-1)^{i} \cdot \delta P_{v 0}$ を考えると, $n$ 回ルールが 修正されたときの性能評価值は，(16)式の関係を繰返 し代入して次式のように求まる.

$$
\begin{aligned}
P_{i+n}= & \left(1-C M^{-1}\right)^{n} P_{i} \\
& +2(-1)^{i+n} \delta P_{v 0}\left\{1-\left(1-C M^{-1}\right)\right. \\
& \left.+\left(1-C M^{-1}\right)^{2} \cdots+(-1)^{n-1}\left(1-C M^{-1}\right)^{n-1}\right\} \\
= & \left(1-C M^{-1}\right)^{n} P_{i} \\
& +(-1)^{i+n} \delta P_{v 0} \frac{1-(-1)^{n}\left(1-C M^{-1}\right)^{n}}{1-C M^{-1} / 2}(17)
\end{aligned}
$$

モデルゲインとその真值の差が小さい場合（|1$\left.C M^{-1} \mid<1\right), n$ が大きくなると(17)式の右辺第 1 項は 無視できる.しかし，外乱の影響を表わす第 2 項は， モデルゲイン $M$ を䛊って設定して $C M^{-1}$ が 2 に近づ くと無視できなくなり（前節 $(14)$ 式で $0 \leq C M^{-1} \leq 2.0$ を仮定), 性能評価值が振動的に発散するととがわか る.

一方，適応ルールを用いる改良学習アルゴリズムに よった場合，(17)式に対応する式はつぎのようにな る.

$P_{i+n}=P_{i} \prod_{k=0}^{n-1}\left(1-C M^{-1} \xi_{j+k}\right)$ 


$$
\begin{aligned}
& +2(-1)^{i+n} \delta p_{v 0} \sum_{k=0}^{n-1}(-1)^{k}\left(1-C M^{-1} \xi_{i+k}\right)^{k} \\
\simeq & \left(1-C M^{-1} \bar{\xi}\right)^{n} P_{i} \\
& +(-1)^{i+n} \delta P_{v 0} \frac{1-(-1)^{n}\left(1-C M^{-1} \bar{\xi}\right)^{n}}{1-C M^{-1} \bar{\xi} / 2}(18)
\end{aligned}
$$

こてで, $\bar{\xi}$ は修正係数 $\xi_{i}, \cdots \xi_{i+n}$ の平均值であり, (14) 式による修正係数の定義から $0<\bar{\xi}<1$ である. 適 忘ルールによれば，外乱の推定量が大きくなると，修 正係数の平均值 $\bar{\xi}$ がより小さくなる. したがって, (18)式に示されたように，外乱がある場合であ性能評 価值が発散するととを防ぐ効果がある.

プラントの応答遅れ時間の推定值に誤りがある場合 には，各時点の制御性能に対して責任が小さい制御ル ールを修正することになるので，ルール修正の効果が 出ずに, 詔った修正が積み重なって性能評価值が発散 してしまう．この対策としては，すでに述べたように ルールの群修正による学習アルゴリズムが有効であ る.

\section{4. 原子カプラントを対象とした シミュレーション}

BWR プラントの圧力制御系に，本論文で提案した 学習機能付ファジィコントローラを適用した場合の制 御特性を, 動特性解析プログラムを用いたシミュレー ションにより解析した. BWR プラントの主要制御系 の構成を Fig. 8 亿示す. 圧力制御系は, 主蒸気流量 を調整して原子炉圧力を一定に制御する，以下，解析 結果から改良学習アルゴリズムの妥当性とファジィコ ントローラによる制御性能改善を評価検討する.

\section{1 学習機能の評価}

圧力制御系は, BWR プラントを安定な運転制御状 態に保っていくための最屯重要な制御系の一つであ り, 制御安定化の効果が大きい. Fig. 9 亿, 適応ルー ルを用いる改良学習アルゴリズムを適用した場合と適 応ルールを用いない従来アルゴリズムを適用した場合 の, 圧力設定点変化に対するプラントの主要制御量の

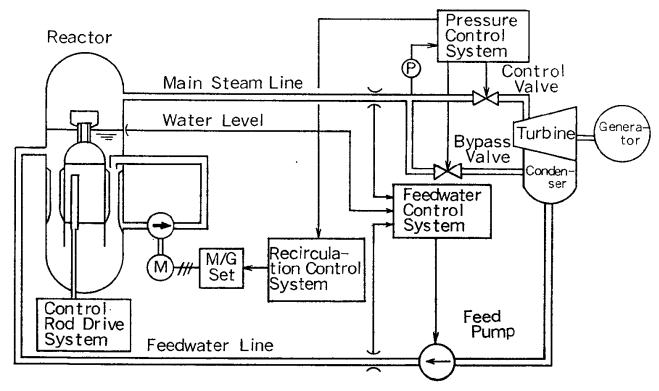

Fig. 8 Major control systems in BWR plants

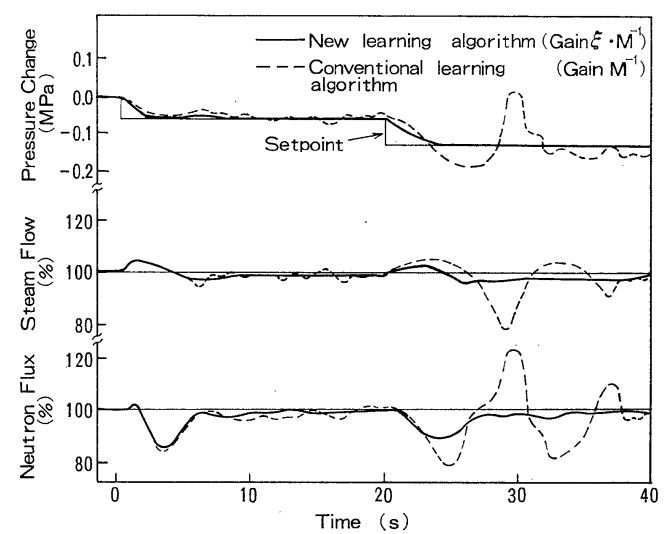

Fig. 9 Comparison of new learning algorithm and conventional one

応答比較を示す．破線で示す従来アルゴリズムの場合 は最初のステップ応答による学習が発散傾向であった ために制御ルールが適切に修正されず，2回目のステ ップ応答で大きく振動している．乙の原因は主に，中 性子束（炉心の中性子密度に比例）の変動が数秒の遅 れをむって原子炉圧力の変動をもたらすてとにより圧 力制御系への外乱となるとと，およびプラントの応答 遅れ時間やモデルゲインの推定誤差によるあのと考え られる.乙れ対し改良学習アルゴリズムによれば, 適応ルールを用いるととにより外乱有と推定した場合 には修正係数 $\xi$ を 1.0 より小さく設定するので $(t \simeq$ $5 \mathrm{~s}$ で $\xi=0.3)$, 誤った学習による制御ルールの過度の 修正を防いで安定な制御特性が得られている. なお， シミュレーションの場合の入力定数を Table 1 亿示 す.

つぎに，事前に制御ルールを与えず（参照テーブル に零を入力), 学習のみにより制御ルールを作成させ

\begin{tabular}{|c|c|c|c|c|}
\hline \multicolumn{2}{|c|}{ Constant } & Symbol & Unit & Value \\
\hline \multicolumn{2}{|c|}{ Sampling period } & $\Delta t$ & s & 0.1 \\
\hline \multicolumn{2}{|c|}{$\begin{array}{l}\text { Sampling number of plant } \\
\text { response delay time }\end{array}$} & $m$ & - & 5.0 \\
\hline \multicolumn{2}{|c|}{ Plant model gain } & $K_{R}$ & psi. s/\% & 0.9 \\
\hline \multicolumn{2}{|c|}{$\begin{array}{l}\text { Time constant of reference } \\
\text { model }\end{array}$} & $T_{m}$ & s & 1.2 \\
\hline \multirow{3}{*}{$\begin{array}{l}\text { Quantization } \\
\text { gain }\end{array}$} & Error & $\Delta e^{*}$ & psi & 2.7 \\
\hline & $\begin{array}{l}\text { Change in } \\
\text { error }\end{array}$ & $\Delta \dot{e}^{*}$ & $\mathrm{psi} / \mathrm{s}$ & 14.1 \\
\hline & $\begin{array}{l}\text { Change in } \\
\text { controller } \\
\text { output }\end{array}$ & $\Delta u^{*}$ & $\% / \mathrm{s}$ & 0.2 \\
\hline
\end{tabular}
た場合の応答シミュレーション結果を Fig. 10 亿示

Table 1 Values used in the simulations 


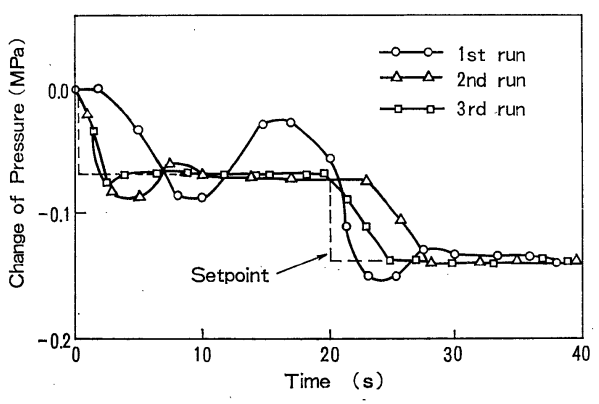

Fig. 10 Improvement of response for setpoint change according to rule learning (Results of BWR presșure control simulated by a dynamic analysis program)
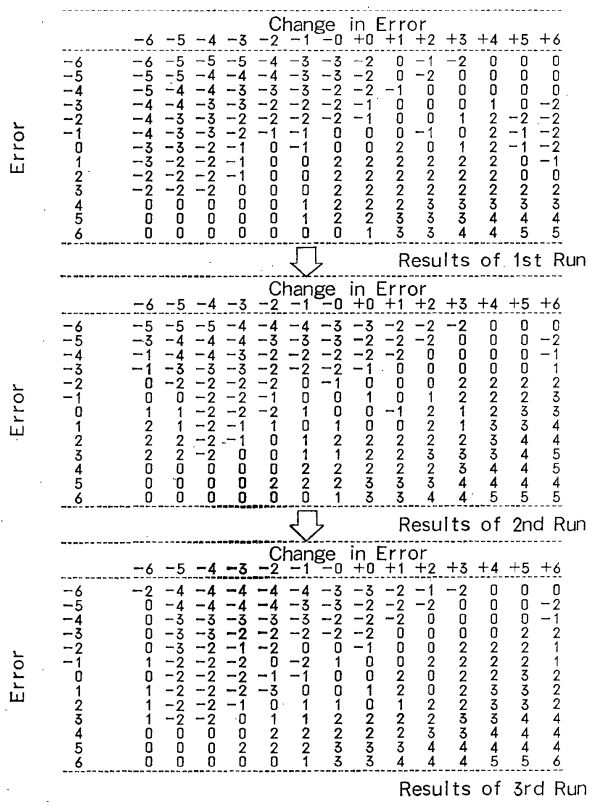

Fig. 11 Changes in the look-up table during the rule learning process

(Values in the table denote changes in controller output. Initial input values are all zeroes)

す. 計算が進むにつれて変動の少ない良好な応答が得 られているととがわかる。この場合の制御ルール学習 のようすを，参照テーブルの印字結果として Fig. 11 に示す，学習でルールを作成させる場合は，改良学習 アルゴリズムによるルールの群修正方式がルールの作 成を加速しているととを確認した。

\section{2 制御特性の比較}

Fig. 12 に, 炉出力を大幅に変えた運転条件でのス テップ応答について，実機で採用している進み／遅れ 補償によるコントローラと学習機能付ファジィコント

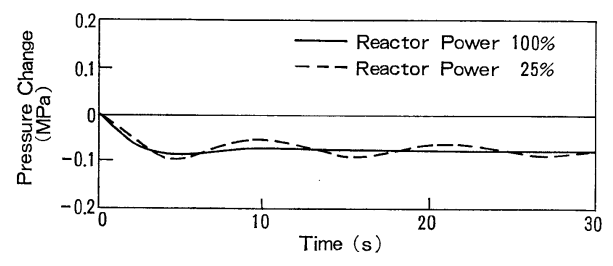

(a) Lead/lag controller

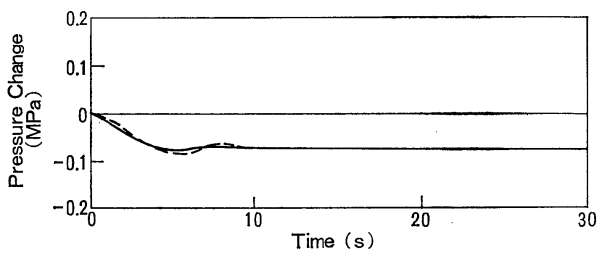

(b) Fuzzy controller

Fig. 12 Responses of the controlled variables in the pressure setpoint change $-0.07 \mathrm{MPa}$

ローラを比較した結果を示す．進み／遅れコントロー ラでは，制御定数を定格出力時の最適值に固定した場 合炉出力が $25 \%$ になるとプラント特性が変化するの で，運転上問題とならないが，やや振動的応答を示し ている，一方，ファジィコントローラでは，学習によ り制御ルールを適切に修正するので，定格運転時と同 様に振動のない応答を示している.

\section{5.おわりに}

本論文ではまず，モデル規範形適応制御系の構成に のっとり，制御の性能評価值に基づいて制御ルールを 修正する学習機能付ファジィコントローラの基本制御 モデルを導出した．との制御モデルを用いて学習機能 付ファジィコントローラにおける学習アルゴリズムを 定式化した.

つぎに，学習の収束性を向上させるために，1) 性 能評価值における外乱の影響を推定し，制御ルール修 正のための修正係数を与えるような，適応ルールを用 いたルール修正方式と，2) 修正するルールとして, 実際に使用されたルールおよびそれと使用条件が隣接 するルール群を選択するような，ルールの群修正方式 からなる改良学習アルゴリズムを提案した.

シミュレーション試験では, 学習機能付ファジィコ

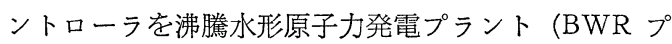
ラント）の圧力制御系に応用した場合に，外乱が多い 環境下での学習収束性が良好で，原子炉出力が異なる 運転条件下でも一様に安定な制御特性が得られること を確認した。

本論文では，主に 1 入力 1 出力系を対象とした学習 
アルゴリズムについて検討したが，多入出力系へ拡張 して適用するためには更に制御系の干渉を考慮する必 要がある.乙れに関しては制御動作の協調を図るため にプラントの制御特性の定性的知識を利用できるの で10)，乙の知識を学習アルゴリズムに活用していくこ とが今後の課題である.

終りに，改良学習アルゴリズムの定式化とシミュレ ーション結果について討論していただいた，(株) 日立 製作所基礎研究所福西宏有主任研究員に深謝します.

\section{参 考 文 献}

1) L.P. Holmblad, et al.: Control of a Cement Kiln by Fuzzy Logic, Fuzzy Information and Decision Process, 389/399, North-Holland (1982)

2) 安信, 宮本, 井原：Fuzzy 制御による列車定位置停止制 御, 計測自動制御学会論文集, 19-11，873/880 (1983)

3) E.H. Mamdani: Application of Fuzzy Algorithms for Control of Simple Dynamic Plant, Proc. IEE, 121-12, 1585/1588 (1974)

4) T. J. Procyk and E.H. Mamdani: A Linguistic Self-Organizing Process Controller, Automatica, 15, 15/30 (1979)

5) 山崎，菅野：自動学習ファジィコントローラ，計測自動 制御学会論文集， 20-8，720/726 (1984)

6) R. V. Monopoli: Liapunov's Method for Adaptive Control System Design, IEEE Trans. Automatic Control, AC-12-3, 334/335 (1967)

7) I. D. Landau: A Hyperstability Criterion for Mode1 Reference Adaptive Control Systems, IEEE Trans. Automatic Control, AC-14-5, 552/555 (1969)

8）山崎，菅野：ファジィ制御，システムと制御，28-7，442/ 446 (1984)

9) 丹治, 福西: ルール制御を用いた原子力発電所自動化制 御方式の検討, 第 24 回 SICE 学術講演会予稿集, 1103 (1985)

10）丹治，ほか：制御系の干渉を考慮したファジィ協調制御 方式の検討, 日本原子力学会昭和 61 年会予稿集, E32 (1986) 